\title{
Relationship Between Advertising and Performance of Micro and Small Architectural Glass Companies in Nairobi County, Kenya
}

\author{
Janeanne Nyagah ${ }^{1 *} \quad$ Lucy Kibe, $\mathrm{PhD}^{2}$ \\ 1 Master of Business Administration (MBA) candidate, Mount Kenya University \\ 2 Lecturer, Mount Kenya University
}

\begin{abstract}
This study was on the relationship between advertising and performance of micro and small enterprises architectural glass companies in Nairobi County, Kenya. The study was anchored on three theories: Attention, Interest, Desire, and Action (AIDA) theory, relationship marketing theory, and the push theory. The study adopted a correlational research design and sampled 124 employees working in Micro and Small Enterprises (SMEs) in nine architectural glass manufacturing firms. Questionnaires and interview schedules were used to collect primary data. The study found out that all aspects of advertising influenced performance of Micro and Small Enterprises architectural glass companies. The study concluded that there was a strong and positive correlation between advertising and the performance of micro and small architectural glass companies. Therefore, the study recommended that micro and small architectural glass companies in Nairobi County should continually embrace advertising because it promoted performance and growth of revenue in the firms.
\end{abstract}

Keywords: advertising, performance, micro and small enterprises, architectural glass companies

DOI: $10.7176 / \mathrm{EJBM} / 12-27-09$

Publication date:September $30^{\text {th }} 2020$

\section{Introduction}

1.1 Background to the Study

Any business seeking to survive in a market with cutthroat competition ought to implement correct marketing strategy to effectively appeal and maintain customer's loyalty. Irrespective of the size, firms urgently need to embrace an advertising strategy that lures and keeps customers loyalty that will build relationships that will last for a long period of time and lead to frequent buying and stable progression in terms performance. This will finally lead to achievement of desired outcomes like higher revenues, increased customer niche and customer loyalty which is also a measure the growth in a competitive market Kinoti (2011).

Micro and small enterprises (MSEs) sector, especially in developing countries, have been exposed to a dynamic business environment due to accelerated globalization of the world economy. Dynamic supply chains and the ever-changing market network of buyer and supplier relationships. In the current consumer market, MSEs' worry a lot about the efforts required to have their product selling, perform optimally and to survive (Barnard, Kritzinger \& Kruger 2011). The efforts made by various MSE's are a result of consumer behaviour change in the acquisition of products and the changing business world. The preference of consumers varies a lot depending on the income, age, education and standard of living. Hence, the success of any MSE business is dependent on the buyer's behaviour. Some of the elements that influence consumer behaviour include culture, social, personal and psychological factors. MSE marketers are therefore compelled to research how consumers respond to marketing stimuli constantly and examine buyer's black box so that they can align their marketing strategies in a way that it will elicit the necessary response (Adwale \& Oyewale 2013).

Advertising elements are direct ways that MSEs use to reach their markets, public and have remained the only strategies that firms apply to gain an advantage over its competitors in the market and enhance their performance (Afande 2015). To wade of competition in a dynamic business environment where consumer needs and wants keep on changing, MSEs are compelled to come up with effective advertising elements that promote growth beyond national boundaries by creating awareness and improving performance through increased utilization of their products and services (Gbolagade \& Oyewale 2013). Promotional strategies allow MSEs to increase customer attraction while at the same time retaining them thus leading to growth in terms of returns on investment because of the increased customer base.

MSEs in the glassware sector in Kenya has been seen to increase in recent years because of a committed, well trained that is committed to producing quality products as per the customers' needs (World Bank 2015). Their growth and success have been attributed to the support of its direct and indirect customers (World Bank 2015). Through their skills in product development in coming up with new products and services, the MSEs in the glass industry is geared to move to the next level of glass processing in Kenya and the region. Most of the glassware MSEs is quickly becoming leading specialists in glassmaking and supply of all types of glasses that meet the safety, visual, security and functional uses within East Africa. The industry draws its customers widely ranging from automotive, rail, marine furniture, and construction industries within the domestic market as multinationals.

These companies have grown from their humble beginnings and now stocks more than 80 different types of 
glasses produced based on styles and the thicknesses of building glass ranging from clear, one way, tinted and obscure, to a variety of oblique and ornamental mirrors. These companies have expanded their products over the years based on market demand and they keep on investing in modern technology enhance their customer service through their creative and motivated workforce in products development and service delivery to the highest level of customer satisfaction.

\subsection{Statement of the Problem}

MSEs in the Kenyan glassware industry has been facing a myriad number of challenges for that last two decades that include competition, economic slowdown recession, including competition, recessions, reputation and brand identification problems (Ardjouman, \& Asma 2015). Additionally, many MSEs in the sector continue to face saturated local markets with dwindling prospective growth. According to Kenya Economic Survey Report (2016), Micro and Small Enterprise sector play a very significant role in the economy of the country and is one of the fastest-growing sectors of the economy that employs $42 \%$ of the working population in the country which accounts for $75 \%$ of the current establishment in Kenya by the year 2014. Micro and Small Enterprises command in the greater part of the country's economic sector, including wholesale and retail business, cafés, hotels, social community services, insurance, land, business administrations, fabricating, farming, transport and correspondence and real estate development (KIPPRA 2017).

Some studies have been undertaken on advertising elements in various fields and sectors across Kenya. While focusing on the women groups in Kisii, Obonyo (2013) found that organizations use sales promotion to improve sales of agricultural and non-agricultural products. According to Munyole (2015), found that integrated marketing mix practices are some of the best strategies for improving organizational performance. Findings by Nana, Gloria, and Kwamena (2011) who focused on the telecommunication industry and service industry respectively showed that the effect of advertising is not significant on firm performance. Thus, limited research exists on the relationship between advertising and performance of Micro and Small Enterprises. This study seeks to analyze the relationship between the advertising and performance of MSEs using a case of architectural glass companies in Nairobi, Kenya.

\subsection{Research Objective}

To assess the relationship between advertising and performance of micro and small architectural glass companies in Nairobi County, Kenya

\section{Literature review}

\subsection{Theoretical Review of Literature}

This study was anchored on three theories that include; Attention, Interest, Desire, Action (AIDA) theory, relationship-marketing theory and push theory. In an attempt to explain how personal operates, Elias St. Elmo Lewis developed the AIDA theory in 1898. The word AIDA is an acronym that stands for Attention, Interest, Desire and Action correspondingly. In marketing and advertising, the model describes the various stages that take place so often when a consumer becomes aware of a product for the first time to the time when the consumer decides to try the product or purchase it (Mahmood \& Fatimah, 2014). Considering that many consumers learn about the products through adverts and marketing communication, the AIDA model aids in explaining how an advert or marketing message engages the consumer to influence the choice of the brand (Horsky \& Honea 2012). According to the model, messages ought to accomplish several tasks required to take the consumer through a sequence of steps from brand awareness. AIDA theory underpins on the objective that is advertising and direct marketing. The theory recommends that messages used in advertising should achieve a number of tasks required to take the consumer through a sequence of stages in brand awareness.

The relationship marketing theory is a conceptualization that came into reality as a response to marketing campaigns that focuses on the retention of customers and their satisfaction instead of focusing only transaction sales (Njomo \& Margaret 2016). The theory stipulates that the strength of long-term relationship develop as the company delivers value to the customer that goes beyond the customer marketing is more concern with long-term customer relationship that transcends invasive advertising and promotional messages (Odhiambo 2013). It recognizes that with the development of the internet-based and mobile platforms, relationship advertising has kept on advancing and pushing ahead as technology keeps on creating more areas of collaboration and social correspondence channels (Saguti 2015).

The push theory of sales and promotion contends that firms carry out the promotion of their goods by targeting the retailer who will, in turn, carry out promotion by selling the same goods to the clients (Saguti 2015). Companies that have adopted push theory as a model of promotion to push up sales by providing incentives to wholesalers or retailers have more of their products sold. In this approach, firms are encouraged to provide discounts to wholesalers or retailers who bulk buy their products. This creates a situation whereby they will remain with more firms' merchandise thus pushing them to sell more of the product. 


\subsection{Empirical Review of Literature}

An advertising strategy is a non-personal communication aimed at a specific audience and channeled through several media outlets to promote a product or a service or a concept (Abiodium \& Paul 2011). The reason for conducting advertising is so that an organization can provide awareness creation on the benefits of its products and let people know about its availability in the market. Advertising therefore plays a very important role in sales and marketing of a product since it influences customer's attitudes, tastes and preferences when making decisions that are related with the product (Belch 2009). It usually carried out using paid as well as free media channels with a large number of the target audience. Agbeja, Adelakun and Akinyemi (2015) points out that companies can advertise using their own established channels whenever they find it that they want to achieve long term or short objectives and still create a long-term relationship. This is because advertising builds up a company's name and brand image (Njawa 2015). According to Akanbi and Adeyeye (2011) organizations using its marketing communication create awareness by impressing customers searching for the finest range of their products.

Advertising intently follows in the strides of institutional promotion whose reason for existing is to create awareness of the items and services of the organizations' name and to publicize the various services on offer. Since glass-fabricating industries serve a big number of people, the issue of brand promotion is knowing who the target audience are and how the advertising will be done (Osogbo 2014).

Abiodium and Paul (2011) explain that the imperative stage in advertising is making sure the service is visible in the minds of the consumers so that risk perception is reduced and provides a clear image of what the product or service is. Mortimer further explains that it is imperative for consistent advertising using a clear image of the brand so that differentiation can be achieved and verbal communication encouraged. Dauda (2015) explains that there exist two different kinds of advertising channels that are considered appropriate which are the above-theline" (ATL) and below-the-line" (BTL) advertising. The Above the line is a form of advertising that comprises the use of various channels of communication that may include magazines, posters, newspapers, television and radio while below-the-line advertising is that which is normally carried out by the company itself by use of Mails to market Directly, Moving from one door to the other while marketing, Outdoor marketing location, marketing using emails among others. Kotler (2012), however, points out that BTL advertising depreciates a brand and undercuts its long term prospects.

Gupta (2015) examined how advertising had affected the performance of companies in three sectors namely; textile, food and automobile industry. The findings from the study indicated that there was a positive relationship between the intensity of advertising on sales while on the other hand the profitability is adversely affected. However, in the automobile industry, the intensity of advertisements had positively affected both the performances as well as profitability. While in the textile and food industry, the findings showed that there was a significantly negative effect on profitability.

According to a study carried out in Kenya with a focus on the sugar industry's advertising performance showed that there was a significant increase in sales volumes but not that significant (Mbithi, Muturi \& Rambo 2015). Further in a study by Kumar and Petersen (2015) that assessed advertising effects on the performance of B2B\& B2C organization established that every tactic adopted in advertising directly affected the performance of the organizations. Organizations that use their resources efficiently and effectively were more likely to carry out streamlining of their marketing efforts that would, in the long run, result in better firm performance.

In a study that investigated the effects of advertising strategy and its effects on firm performance in china found out that customer orientation has the strongest connection with firm performance. Customer orientation was found to have the strongest association with market performance (Ge \& Ding 2013). In a similar study conducted in Kenya with the focus on the influence that advertising had on print media found out that the revenues of print media as well as their performance were significantly affected by advertising (Nyamamu 2011). The study involved four mainstream media houses in Kenya that included Kenya Television Network (KTN), Citizen Media house, Nation Media Group, Media Max, Standard group and radio group, Africa. The study also noted that digital platforms are emerging as the future frontier through which business advertising competition will take place.

Finally, an assessment of advertising and performance has always focused on the motor vehicle industry, textile, food processing and print media industry in Kenya. This current study looked at how advertising affects the performance in MSEs dealing with architectural glass to bridge the existing gap.

\section{Research Methodology}

The mixed research methodology was adopted in the study. The methodology uses both qualitative and quantitative aspects which provide an in-depth understanding of the study which either of the other would provide independently (Kothari 2004)

\subsection{Research Design}

The correlational research design was used in this study because of its appropriateness to the nature of this study which is non-experimental and which requires the researcher to measure two variables and statistically examine 
their relationship such as the correlation between them without being influenced by extraneous variables.

\subsection{Location of the Study}

Nairobi County was the location where the study was carried and it involved micro and small enterprises with a focus on the architectural glass companies. Most of the company's headquarter operations are in Nairobi a hub of most of the industrial and economic activities hub that hosts most of the target companies. Besides, the construction and real estate developments within and around Nairobi provides a ready market for the glass companies. These characteristic makes Nairobi suitable for the study.

\subsection{Target Population}

The study's population constituted all MSEs with the glass manufacturing industry in Nairobi County. The population target for the study was employees in the architectural glass manufacturing MSES within Nairobi County. The units of observation was 124 members of staff from nine MSEs in the architectural glass manufacturing sector. They were sales managers, accountants and regular staff of MSEs in Nairobi County, Kenya.

Table 1. Target Population Size

\begin{tabular}{|c|c|c|c|c|c|}
\hline \multicolumn{2}{|c|}{ MSEs } & \multicolumn{2}{|l|}{ Managers } & $\begin{array}{l}\text { Regular } \\
\text { Staffs }\end{array}$ & Population \\
\hline 1 . & Essajee Amijee EA Ltd & 1 & 3 & 16 & 20 \\
\hline 2. & Impala Glass Industries Ltd & 1 & 3 & 14 & 18 \\
\hline 3. & Smart Glass Industries Ltd & 1 & 1 & 14 & 16 \\
\hline 4. & Hebatullah brothers Ltd & 1 & 2 & 11 & 14 \\
\hline 5. & Husseini Glass Kenya Ltd & 1 & 1 & 9 & 11 \\
\hline 6. & Cannon Aluminum & 1 & 2 & 13 & 16 \\
\hline 7. & Mufaddal Glass Distributors & 1 & 1 & 7 & 9 \\
\hline 8. & Saifee Silvering & 1 & 1 & 10 & 12 \\
\hline 9. & Glass East Africa & 1 & 1 & 6 & 8 \\
\hline Tota & & 9 & 15 & 100 & 124 \\
\hline
\end{tabular}

Source: (NCC, 219)

\subsection{Sample Population}

Because of the aspects of the study population such as its small number, the researcher used census sampling because it was a manageable Micro and Small Enterprises (MSEs) population that was classified under architecture al glass companies. The reason for using this sampling method was because the population was made of numerous subgroups that are widely diverse in size but have a smaller target population. The relativity to the entire population was used to identify the number of participants from every group. Therefore, the sample size of this study was $100 \%$ of the target population using census survey which was 124 respondents.

\subsection{Data Collection Methods and Procedures}

The researcher designed a questionnaire in line with research objectives and used it to collect primary data from the informants by individually administering the questionnaires. Interview schedules were also used because they allowed for personal interaction with the respondents that made it easier for the researcher to explain and elaborate further the question to enhance the findings. The interview also allowed the researcher to read the nonverbal language of the interviewees to determine whether he/she was honest or not.

\subsection{Data Analysis Techniques and Procedures}

The Statistical Package for the Social Sciences (SPSS) was used to analyze the quantitative data. The analyzed data was then presented using frequencies, percentages, means and standard deviations in a report format by use of tables. Qualitative data was analyzed thematically whereby text from diverse sources such as interviews, field notes and other forms of written data.

Linear regression and Pearson correlation were utilized to establish the relationship between the study variables. The relationship between the independent and dependent variables was modelled using the following linear regression model:

Where,

$$
Y=\beta_{0}+\beta_{1} X_{1}+\varepsilon
$$

$Y$ is the performance

$\beta_{0}$ is constant

$X_{I}$ is advertising

$\beta_{l}$ is a regression coefficient

$\varepsilon$ is an error term 


\section{Findings}

\subsection{Demographic Information}

Table 2. Time Frame at the Company

\begin{tabular}{lll}
\hline Category & Frequency & Percentage \\
\hline Less than 1 Year & 16 & 16 \\
$1-2$ years & 20 & 20 \\
3-4 Years & 25 & 26 \\
4- 5Years & 12 & 12 \\
More than 5 Years & 25 & 26 \\
\hline Total & 98 & 100 \\
\hline
\end{tabular}

Source: Research Data (2020)

When the respondents were asked to indicate or report their age bracket based on the number of year of years they been working in the company and the responses were shown above with less than 1 year was shown by $16 \%$, $1-2$ years was shown by $20 \%, 3-4$ years was shown by $26 \%, 4-5$ years was shown by $12 \%$ and more than 5 years was shown by 26. This implies that many of the respondents had been working for the their company for 3-4 years and more than 5 years and it is assumed that they had sufficient knowledge and experience to comprehend advertising and performance of micro and small architectural glass companies they worked for.

Table 3. Level of Education

\begin{tabular}{lll}
\hline Level of Education & Frequency & Percentage \\
\hline Certificate & 33 & 34 \\
Diploma & 34 & 35 \\
Degree & 19 & 19 \\
Masters & 10 & 10 \\
Doctorate & 2 & 2 \\
\hline Total & 98 & 100 \\
\hline
\end{tabular}

Source: Research Data (2020)

Education levels also have an effect on decision making processes of an individual. Highly educated individuals tend to be more analytical than those who have fewer qualifications. Though not every individual employed by the company had management role, those whose academic qualification was lower were only required to do some tasks in marketing department of the organization. In the same way, they had their views. For this study respondents were asked their level of education and the results were as follows, those who had certificate level was shown by 34 percent, those who had diploma course was shown by 35 percent and those who had undergraduate level and above were $32 \%$. The entire group were able to understand and respond to the questions about advertising appropriately.

\subsection{Relationship between Advertising and Performance}

The study sought to assess relationship between advertising and performance of micro and small architectural glass companies in Nairobi County, Kenya. Respondents were posed with questions on advertising parameters using five point Likert scale and their responses were analyzed and presented as in Table 4 as follows

Table 4. Advertising Parameters

\begin{tabular}{|c|c|c|c|}
\hline Advertising & $\mathrm{N}$ & Mean & S.D \\
\hline a) Electronic Media & 98 & 4.001 & 0.999 \\
\hline b) Print Media & 98 & 4.997 & 0.003 \\
\hline c) Outdoor Publicity & 98 & 4.908 & 0.092 \\
\hline
\end{tabular}

Source: Research Data (2020)

Based on data collected majority of respondents were of the opinion that electronic media affect performance of micro and small architectural glass companies as it can be seen in the recorded mean score of 4.001 with a standard deviation of 0.999 , print media at a mean score of 4.997 and with a standard deviation of 0.003 and outdoor publicity at a mean score of 4.908 with a standard deviation of 0.092 . This implies that the majority of the respondents strongly supported advertising parameters in their companies.

Table 5. Advertising Statement

\begin{tabular}{rlccl}
\hline Statements & $\mathrm{N}$ & Mean & S.D \\
\hline a) Information sharing through electronic media its high & 98 & 4.197 & 0.803 \\
b) Public get more information through their print media & 98 & 4.917 & 0.083 \\
c) Sales its done through outdoor publicity & 98 & 4.524 & 0.476 \\
\hline
\end{tabular}

Source: Research Data (2020)

Based on the findings the respondents agreed that information sharing through electronic media its high with a mean score of 4.197 and with a standard deviation of 0.803 , according to the study finding other respondents 
reported strongly agreed that public get more information through their print media as was shown by a mean score of 4.917 and with a standard deviation of 0.083 consequently on the same scale the respondents also strongly agreed that sales its done through outdoor publicity with a mean score of 4.524 and a standard deviation of 0.476 . This implies that the respondents strongly agreed that public get more information through their print media as an advertising strategy.

Table 6. Advertising in Relation to Competitiveness

\begin{tabular}{lll}
\hline Category & Frequency & Percentage \\
\hline Extremely competitive & 36 & 37 \\
Very competitive & 29 & 30 \\
Competitive & 16 & 16 \\
Less competitive & 8 & 8 \\
Not Competitive & 9 & 9 \\
Total & 98 & 100 \\
\hline
\end{tabular}

Source: Research Data (2020)

The respondents were asked if advertising has affected the rate of competitiveness of their company in the Kenyan Market. 83\%stated that it's it was most effective while 8\% stated that is less competitive, with only $9 \%$ of the respondents stated that it's not competitive. This implies that advertising has affected the rate of competitiveness of their company in the Kenyan Market as extremely competitive. Hence the companies use advertising as the way forward to impact performance.

Table 7. Advertising on influence to Company's Performance

\begin{tabular}{lll}
\hline Category & Frequency & Percentage \\
\hline Not at all & 3 & 3 \\
Least extent & 4 & 4 \\
Moderate extent & 20 & 20 \\
Great extent & 37 & 38 \\
Very Great Extent & 34 & 35 \\
\hline Total & 98 & 100 \\
\hline
\end{tabular}

Source: Research Data (2020)

Based on the findings the respondents were asked to state the extent on advertising has affected their company's performance in the past 3 years. According to the findings 93\%the respondents agreed that advertising has affected the company's performance, only $7 \%$ were not certain about the effects of advertising. In their own opinion, the respondents stated that most of their customers get to know about their company's information and products through media marketing and referrals from their customers. This implies that advertising influences the company performance and that if no advertising was done by the in the company the customers will not be informed of their products that are on sale.

4.3 Correlation Analysis

In Table 8 the representation summary of correlation which indicates existence of relationship between independent and dependent variables with a significance of $95 \%$ confidence levels.

Table 8. Correlation Analysis

\begin{tabular}{llllll}
\hline & & Performance & Advertising & $\begin{array}{l}\text { Sales } \\
\text { Promotion }\end{array}$ & $\begin{array}{l}\text { Direct } \\
\text { Marketing }\end{array}$ \\
\hline Performance & Pearson & 1 & $.738^{* *}$ & .264 & $.374^{*}$ \\
& $\begin{array}{l}\text { Correlation } \\
\text { Advertising }\end{array}$ & & & & 98 \\
& $\mathrm{~N}$ & 98 & 98 & 98 & $.465^{* *}$ \\
& $\begin{array}{l}\text { Pearson } \\
\text { Correlation }\end{array}$ & $.738^{* *}$ & 1 & $.471^{* *}$ & 98 \\
\hline
\end{tabular}

**. Correlation is significant at the 0.05 level (2-tailed).

Source: Research Data (2020)

Advertising had a strong positive Pearson correlation of $0.738 ; 0.471$; and 0.465 with performance of micro and small architectural glass companies; sales promotion; and direct marketing respectively. This implies that advertising positively relates with performance, sales promotion and direct marketing.

\subsection{Regression Analysis}

Linear regression analysis was done to establish the relationship between advertising and performance of micro and small architectural glass companies. The analysis was undertaken at $95 \%$ confidence level and $5 \%$ significance level. 


\begin{tabular}{llllc}
\hline \multicolumn{5}{c}{ Table 9. Model Summary } \\
\hline Model & $\mathrm{R}$ & $\mathrm{R}$ Square & Adjusted R Square & Std. Error of the Estimate \\
\hline 1 & $.874^{\mathrm{a}}$ & .763 & .755 & .97669 \\
a. Predictors: & (Constant), Advertising & &
\end{tabular}

a. Predictors: (Constant), Advertising

Source: Research Data (2020)

The coefficient of multiple determinations $\left(\mathrm{R}^{2}\right)$, is the percentage of the variance in the dependent (Performance of Micro and Small Architectural Glass Companies) explained by the independent variab1e (advertising). The model had $\left(\mathrm{R}^{2}\right)$ of 0.763 and which implied that $76.3 \%$ of the variation in performance of Micro and Small Architectural Glass Companies was explained by advertising.

Table 10. Coefficients

\begin{tabular}{|c|c|c|c|c|c|c|}
\hline \multirow[t]{2}{*}{ Model } & & \multicolumn{2}{|c|}{ Unstandardized Coefficients } & Standardized & \multirow[t]{2}{*}{$\mathrm{T}$} & \multirow[t]{2}{*}{ Sig. } \\
\hline & & B & Std. Error & Beta & & \\
\hline \multirow{2}{*}{1} & (Constant) & 5.728 & 2.129 & & 2.690 & .000 \\
\hline & Advertising & .311 & .064 & .212 & 4.859 & .004 \\
\hline
\end{tabular}

a. Dependent Variable: Performance

Source: Research Data (2020)

The established model for the study was:

$\mathrm{Y}=5.728+0.311 \mathrm{X}_{1}+\varepsilon$

From the regression model obtained above, taking constant all other factors, performance of Micro and small scale Architectural Glass companies would be 5.728 units. A unit variation in the advertising keeping other factors constant would 1ead to change in performance by 0.311 units. Based on the stipulated criteria for testing significance, the study found out that at $5 \%$ leve1 of significance the predicator variable was significant since their corresponding probability value was less than significance leve1 $(\alpha=0.05)$.

\section{Discussion}

According to the analyzed data outcome on advertising most of respondents agreed electronic media affect performance of micro and small architectural glass companies; and other respondents reported that the print media affect performance. According to data analysis findings majority of the respondents strongly agreed that advertisements effects performance with an average score of 4.997 and standard deviation of 0.003 . This shows that electronic media advertising can be done using various channels, such as search engine optimization, content marketing and social media marketing. Based on the findings majority of the respondents strongly agreed that public get more information through their print media as was shown by a mean score of 4.917 and with a standard deviation of 0.803 consequently on the same scale the respondents also strongly agreed that sales its done through outdoor publicity with a mean score of 4.524 and a standard deviation of 0.476 . Advertising is correlated with performance of micro and small architectural glass companies positively as was shown by a Pearson correlation of 0.738 . This agrees with other scholars who posited that advertising builds up a company's name and brand image (Njawa 2015) and Afande (2015). Kumar and Petersen (2015) established that every tactic adopted in advertising directly affected the performance of the organizations.

In addition, advertising correlated positively with sales promotion with a Pearson correlation of 0.471 showing statistically significant relationship. On the same scale advertising correlated positively with direct marketing with a Pearson correlation of 0.465 . This implies that advertising positively relates with performance. This shows that advertising over print media and outdoor publicity is still considered as a new phenomenon and waits for news insights, propagations and findings. In many instance, it has been found that the effect of advertising is insignificant and in some cases negative because people perceive advertisements as carrying have truth messages and most often it is full of deception. Lack of legal administration gave lee way to advertisers to over exaggerate the attributes and performance of their products to the levels where people lost confidence in the message being passed across to consumers. Though there are some messages which are valued. These statements agrees with Belch (2009) who posits that reason for conducting advertising is so that an organization can provide awareness creation on the benefits of its products and let people know about its availability in the market. Advertising therefore plays a very important role in sales and marketing of a product since it influences customer's attitudes, tastes and preferences when making decisions that are related with the product.

\section{Conclusion}

The study established that there was a strong positive connection between advertising and performance and concluded that micro and small architectural glass companies should focus more on advertising because it significantly effects on performance. Findings postulated a positive significant between advertising and performance. The study concludes that organizations that use advertising in promoting their products or services below its normal market range so as to win more fast market acceptance or to expand the market share that it 
currently controls. The study also concludes that advertising is a basis of competitive advantage and customers seek to be informed and may pay more if they perceive they are getting more inf0rmed from the service/ product provider. AIDA theory, relationship marketing theory and push theory support the conclusions on advertising aspects in relation to acceptance and consumption of goods is concerned hence supports the findings of this research

\section{Implication to Research and Practice}

Information to aid glassware companies as well as other industry stakeholders in finding viable advertising elements that are likely to push up the sales and increase revenues through market share expansion. Additionally, the findings may be used by the government and various stakeholders in the glassware industry in policy formulation and implementation to promote the performance of MSEs. The study outcomes will add to the existing body of knowledge on elements advertising that are useful for adoption in the glassware industry in Kenya. In future, the scholars may use the study findings to further the studies in advertising effects on market share and performance.

From the findings it is recommended that micro and small architectural glass companies in Nairobi County should continually embrace advertising as a tool through which creation of new products as well as improvement will be realized. Even though successful $\mathrm{m}$ advertising may increase profitability through increased revenues, it is also imperative to plan carefully to reduce risks and costly errors that are associated with the strategy. Advertising, together with other studied factors are imperative in providing businesses with guidance on financial goals development. Micro and small architectural glass companies ought to identify a strategic location for marketing which is convenient for clients.

\section{Future Research}

The study focused on to establishing the Relationship between advertising and performance of micro and small architectural glass companies. Further studies ought to be carried out on determinants of advertising in micro and small architectural glass companies sector in Kenya. It is also important to carry out investigation on the relationship between adverting in retail sectors in Kenya but this will have a larger sample that includes the customers of the glass materials in the construction industry, which is customer focus on the industry. This will help in comparison of adverting in micro and small architectural glass companies and retail sectors.

\section{References}

Abiodium, A., Paul, M. \& Adeyeye, T. (2011), "Sales relationship between advertising for selected companies operating in Nigeria", Journal of administration, university of Nigeria, Nsukka 4 (3). Retrieved from https://www.researchgate.net/publication/337732856_The_role_of_advertising_on_the_increase_of_a_com pany's_revenue_LC_Waikiki_in_Sulaimani_as_a_case_study

Adwale, M. A., Gbolagade, A. \& 0yewa1e, I. 0. (2013), "Impact 0f Marketing Strategy on Business Performance. A Study of Selected Sma11 and Medium Enterprises (SMEs)", Journal Of Business and Management 11(9), 59-66.

Afande, F. O. (2015), "Effect of Promotional Mix Elements on Sales Volume of Financial Institutions in Kenya: Case Study of Kenya Post Office Savings Bank", Journal of Marketing and Consumer Research 11, 64. Retrieved from https://www.iiste.org/Journals/index.php/JMCR/article/view/22439

Agbeja, O., Adelakun, O. J. \& Akinyemi, D. (2015), "Analysis of the Effect of Advertising on Sales and Profitability of Company", International Journal of Novel Research in Marketing Management and Economics 2(3), 81-90. from https://www.researchgate.net/publication/332082745_Analysis_of_the_Effect_of_Advertising_on_Sales_an d_Profitability_of_Company

Akanbi, P. A. \& Adeyeye, T. C. (2011), “The Association between Advertising and Sales Volume: A Case Study of Nigerian Bottling Company PlcAkanbi”, Journal of Emerging Trends in Economics and Management Sciences 2(2), 117-123. Retrieved from http://erepo.usiu.ac.ke/bitstream/handle/11732/3664/MICHAEL\%20MWENDA\%20GITUMA\%20MBA\% 202017.pdf?sequence $=1 \&$ isAllowed $=\mathrm{y}$

Ardjouman, D. \& Asma, B. (2015), "Marketing Management Strategies Affecting Performance of Enterprises (SMEs) in Cote d'Ivoire", International Journal of Business and Social Science 6(4), 141-150

Barnard, S., Kritzinger, B. \& Krüger, J. (2011), "Location decision strategies for improving SMME business performance", ActaCommercii.

Belch, G. \& Belch, M. (2009), Advertising and Promotion: An Integrated Marketing Communications Perspective. 8th ed. Maidenhead: McGraw-Hill.

Dauda, A. (2015), "Effect of advertising on the sales revenue and profitability of selected food and beverages firms in Nigeria", Unpub1ished Thesis Submitted to Ahmadu Be11o University, Zaria. 
Gbolagade, A., Adeso1, M. A. \& 0yewa1e, I., 0. (2013), "Impact of Marketing Strategy on Business Perf0rmance. A Study of Selected Sma11 and Medium Enterprises (SMEs)", Journal of Business and Management, 11(9), 59-66.

Ge, G. I. \& Ding, D. Z. (2013), "Effects of an Advertising Strategy on Firm Perf0rmance in China: An Empirica1 Study of Chinese Firms", Journal of Global Marketing 18(3), 33 - 45.

Gupta, N. (2015), "Effect of Advertisement on the Firms' Performance: An Empirical Analysis", Marketing Science 19(4), $390-396$.

Horsky, S. \& Honea, H. (2012), "The power of plain: Intensifying product experience with neutral aesthetic context", Marketing letters 23 (1), 223-235.

Kinoti, M. W. (2011), Green marketing intervention strategies and sustainable development: A conceptual paper. International Journal of Business and Social Science, 2(23).

KIPPRA. (2017), “A Case Study on Effect of Promotiona1 E1ement on Sa1es in Service Industries”, Journa1 of International Marketing 6(1), 56-68.

Kothari, C. R. (2004), Research Methodology: Methods and Techniques. 2nd Ed. USA, USA: New Age Internati0na1 Publishers.

Kot1er, P. \& Armstrong, G. (2012), Principles of Marketing. 14 ${ }^{\text {th }}$ Ed. USA: Pearson Ha11.

Kumar, V. \& Petersen, J. A. (2015), "Advertising on the Performance of B2B and B2C Firms: A Review of Theoretica1 and Empirica1 Evidence", Journal of the Academy of Marketing Science 33(4).

Mahmood, M. H. \& Fatimah, H., (2014), "The Effect of Product Qua1ity on Business Performance in Some Arab Companies", Journal of Emerging Trends in Economics and Management Sciences 5(5), 498-508.

Mbithi, B., Muturi, W. \& Rambo, C. (2015), "Effect of Market Deve1opment Strategy on Perf0rmance in Sugar Industry in Kenya", InternatiOnal Journal of Academic Research in Business and Social Sciences 5(12), $311-325$.

Munyole, P. N. (2015), "Direct Marketing Strategies Adopted by Veterinary Pharmaceutica1 Firms in Kenya to Enhance PerfOrmance", Journal of the Academy of Marketing Science 33(3), 44 - 65.

Nairobi City County (NCC). (2019), Government of Kenya, Nairobi City County Report of Registered Companies. Nairobi.

Nana, Y. D., G1oria K. Q. \& Kwamena, M., N. (2011), "The Effect of Marketing Communications on the Sa1 es Performance of Ghana Telecom (Vodafone, Ghana)", InternatiOnal Journal of Marketing Studies, 3 (4).

Njawa, J. (2015), "The effects of advertising on organizational performance: A case Study of TIGO Telecommunication Network Junior", Unpublished Thesis Submitted to Mzumbe University.

Njomo, G. W. \& Margaret, 0. (2016), "Market Penetration Strategies and organizati0nal Growth: A Case of Soft Drink", International Journal of Management and Commerce Innovations, 3 (2), 219-227.

Nyamamu, C. F (2011), "The Influence of Advertising on Perf0rmance of Print Media Companies in Kenya", Journal of Marketing, 46(3), 46 - 55.

0bonyo, G. 0. (2013), "Evaluating marketing strategies adopted by supermarkets for competitive edge: A case of Kisii town supermarkets", Interdisciplinary Journal of Contemporary Research in Business, 4 (12), 15-40.

Odhiambo, M. (2013), "Effect of pricing as a Competitive Strategy on Sales Performance of Selected Pharmaceutica1 Companies", Unpub1ished Thesis Submitted to University of Nairobi.

Osogbo, R. (2014), "Effects of Advertising on organizationa1 Profitability", Journal of Management and Social Sciences 3(1), 67.

Saguti, J. F. (2015), "The effects of marketing mix on sales performance of TigoTelecommunication Company in Tanzania", Unpublished Thesis Submitted to Muzumbe University Dar-es-Sa1aam.

World Bank. (2015), Improving Competitiveness of Manufacturing in Kenya. World Bank Summary Trade Statistics Kenya, Geneva. documents.wor1dbank.org/curated/en/645741468339541646/pdf/928630WDR0978100B0x385358B00PU B1IC0.pdf. 